\title{
Development of the Four-cylinder Moving Mesh Model for a 1.6-litre Four-stroke Direct-injection Engine
}

\author{
Shahrir Abdullah, Wendy Hardyono Kurniawan, Kamaruzzaman Sopian and Zulkifli Mohd Nopiah \\ Department of Mechanical and Materials Engineering \\ Universiti Kebangsaan Malaysia \\ 43600 UKM Bangi, Selangor, \\ Malaysia \\ Email :shahrir@eng.ukm.my \\ Received Date: $28^{\text {th }}$ August 2006 Accepted Date: $7^{\text {th }}$ March 2007
}

\begin{abstract}
The design of a modern internal combustion engine requires the use of advanced analysis and development tools to carry out an in-depth investigation on internal combustion process and computational fluid dynamics (CFD) simulation by using high performance computers. In this work, the algorithm for moving or deformed mesh for a 1.6-litre four-cylinder four-stroke direct-injection engine has been developed. This type of mesh is required for transient simulation of fluid flow and combustion process inside the combustion chamber of an internal combustion engine. This mesh deforms with the movement of intake and exhaust valves as well as piston. Hence, the purpose of the work is to verify the moving mesh algorithm and to establish the correct mesh configuration at any crank angle.The simulation covers the full engine cycle consisting of intake, compression, power and exhaust strokes and the order of piston motion is set according to the firing order of the selected engine. The algorithm established defines events in which any of the designated engine component moves in terms of time and duration of occurrence. The verification of the algorithm was performed for the whole four-stroke cycle of $720^{\circ}$ crank angles, where the positions of the intake valve, exhaust valve, cylinder and piston were updated accordingly with respect to crank angle. The finalised algorithm and mesh can be used to simulate the in-cylinder fluid flow and internal combustion process for the full engine cycle.
\end{abstract}

Keywords: Computational fluid dynamics, moving mesh, direct-injection, four-stroke cycle, internal combustion engine.

\section{ABSTRAK}

Reka bentuk enjin pembakaran dalaman moden memerlukan penggunaan analisis termaju dan peralatan pembangunan untuk menjalankan kajian yang mendalam terhadap proses pembakaran dalaman dan simulasi dinamik bendalir komputeran (CFD) dengan menggunakan komputer berprestasi tinggi. Dalam kajian ini, algoritma untuk jejaring bergerak atau berubah bentuk daripada enjin suntikan terus empat lejang empat silinder 1.6 liter dibangunkan. Jenis jejaring ini diperlukan untuk simulasi tidak mantap daripada aliran bendalir dan proses pembakaran di dalam kebuk pembakaran sebuah enjin pembakaran dalam. Jejaring ini berubah bersamaan dengan pergerakan injap pengambilan dan ekzos serta omboh. Oleh itu, 
objektif kajian ialah untuk mengesahkan algoritma jejaring bergerak dan mewujudkan konfigurasi jejaring yang tepat pada sebarang sudut engkol. Simulasi yang dilakukan meliputi kitar enjin penuh yang terdiri daripada lejang pengambilan, mampatan, kuasa dan ekzos serta aturan pergerakan omboh disetkan mengikut urutan nyalaan untuk enjin berkenaan. Algoritma yang dibangunkan mendefinisikan peristiwa-peristiwa di mana sebarang komponen enjin berkenaan bergerak dalam ungkapan masa dan tempoh urutan. Pengesahan algoritma dijalankan untuk keseluruhan kitar empat lejang daripada $720^{\circ}$ sudut engkol, di mana kedudukan-kedudukan daripada injap pengambilan, injap ekzos, silinder dan omboh dikemaskinikan mengikut sudut engkol. Algoritma dan jejaring akhir dapat digunakan untuk mensimulasikan aliran bendalir dalam silinder dan proses pembakaran dalam untuk kitar enjin penuh.

Kata kunci: Dinamik bendalir komputeran, jejaring bergerak, suntikan terus, kitar empat lejang, enjin pembakaran dalam.

\section{INTRODUCTION}

It is well known that reciprocating engines can produce many complex characteristics and phenomena, which perhaps more complex than any other mechanical devices. Even though the internal combustion (IC) technology has developed tremendously over the last few decades, there are still areas of improvement which can be explored.With stringent regulations and emission control policies, stiff competition among car manufacturers and increasing customers' demands, automotive engineers have been strived to design increasingly sophisticated solutions in order to achieve better performance and cleaner engines. To cope with the demands, control over combustion process is a popular approach used by many researchers nowadays. However, due to the complexity of the IC process itself, careful study has to be conducted on any new innovation introduced on the engine in order to make sure that the engine is marketable.

Nowadays, the development of an IC engine requires the use of advanced analysis and tools, such as computer-aided design (CAD) and computer-aided engineering (CAE) software. In addition to the experimental work carried out on engine test rigs, numerical simulation via CAE software such as computational fluid dynamics (CFD) software can be used to analyse and to optimise the engine. In order to accurately simulate the IC process, the mesh has to be created in such a way that it can deform according to several moving components that form the combustion chamber, namely the piston crown and the intake and exhaust valves. In this case, boundaries of the computational domain have to be allowed to move which eventually shrink or expand the fluid volume in accordance to crank angle.
In fluid flow calculations the utilisation of moving coordinates is absolutely essential, especially in flows with moving boundaries as occurred in IC engine. The solution of such problems is best carried out through the conservation equations in a non-Eulerian coordinate frame. Due to the movement of the coordinate system, an additional equation is required to be satisfied simultaneously with the other conservation equations. This equation relates the change of the elementary control volume to the coordinate frame velocity and is called firstly by Trulio and Trigger (1961) as the space conservation law. They have included the space conservation law equation together with the mass, momentum and energy transport equations in their fundamental equations of motion for numerical solutions on moving meshes and used it for one-dimensional flow calculations. However, the necessity of solving this equation simultaneously with the other conservation was not recognized until it was rediscovered by Thomas and Lombard (1979) and Demirdžic (1982). Trulio and Trigger (1961) and Thomas and Lombard (1979) used the space conservation law equation with a finite difference solution method. Warsi (1981) also recognise the space conservation law equations as the fundamental equation for non-steady coordinates. The concept of moving mesh with the integration of finite volume formulation as implemented in the CFD calculation method has been introduced by Demirdžic and Peric (1988).

Simulation of IC processes had been attempted by a number of researchers. Demirdžic and Muzaferija (1995) presented a numerical method for flow predictions in an air-cooled internal combustion engine by using unstructured moving meshes with cells of arbitrary topology. The developed numerical method has been 
tested for any application in fluid flow, stress analysis and heat transfer. Chen et al. (1998) performed calculations of the full intake and compression strokes and presented some comparisons with the experimental data. However, their results showed that the turbulent velocity is under-predicted due to limitation in the standard $k-\varepsilon$ model. Hyun et al. (2000) also carried out the CFD simulation using KIVA-3 where the shape of combustion chamber, swirl intensity and injection timing were modified for the LPG direct injection engine in order to study the effect of different type of combustion chamber by using various piston crowns. Rifai et al. (2000) has utilised the arbitrary LagrangianEulerian (ALE) method to account the problem in the deformable fluid domains and the brought case study was exhaust and intake stroke of an example of internal combustion engine.

Abd-Alla (2001) had performed a study on a four-stroke spark ignition engine in order to determine the cylinder pressure for the whole four-stroke cycle via empirical formulation and the result obtained was inline with the experimental result. The moving mesh approach had been utilised by Choi et al.(2001) to simulate the combustion process in a spark ignition engine in order to predict oxidation velocity of unburned hydrocarbon inside combustion chamber. In addition, Yasar (2001) has developed a new ignition model by employing the ALE method incorporated inside KIVA-3V code to simulate engine combustion and fluid flow. Lately, Payri et al. (2004) carried out CFD simulation on the incylinder flow for a direct-injection Diesel engine for intake and compression stroke using various combustion chambers and validated their numerical result with the experimental work.

Since the success and accuracy of a CFD simulation is much dependent on the geometry of computational domain as well as the right boundary conditions and formulation, obtaining the actual mesh is of high importance. This has to be accomplished prior to CFD simulation, which is in-cylinder fluid flow and combustion simulation. Apart from the deformed computational domain, the nature of such problem is unsteady or transient, compressible, highly turbulent,

TABLE 1. Specification of the engine model

\begin{tabular}{lc}
\hline Engine Parameter & Value \\
\hline Bore $(\mathrm{mm})$ & 78 \\
Stroke (mm) & 84 \\
Capacity (c.c.) & 1596 \\
Number of cylinders & 4 \\
Connecting rod length (mm) & 131 \\
Crank radius (mm) & 44 \\
Piston pin offset (mm) & 0.0 \\
Crank angle start ( $\left.{ }^{\circ} \mathrm{CA}\right)$ & $348^{\circ}$ \\
Crank angle stop ( $\left.{ }^{\circ} \mathrm{CA}\right)$ & $1080^{\circ}$ \\
Intake valve open ( $\left.{ }^{\circ} \mathrm{CA}\right)$ & $12^{\circ} \mathrm{BTDC}$ \\
Intake valve close ( $\left.{ }^{\circ} \mathrm{CA}\right)$ & $48^{\circ} \mathrm{ABDC}$ \\
Exhaust valve open ( $\left.{ }^{\circ} \mathrm{CA}\right)$ & $45^{\circ} \mathrm{BBDC}$ \\
Exhaust valve close $\left({ }^{\circ} \mathrm{CA}\right)$ & $10^{\circ} \mathrm{ATDC}$ \\
Maximum intake valve $(\mathrm{mm})$ & 8.1 \\
Maximum exhaust valve $(\mathrm{mm})$ & 7.5 \\
Valve lift periodicity (deg) & $360^{\circ}$ \\
\hline
\end{tabular}


chemically reacting due to combustion of airfuel mixture and multiphase in the case of liquid fuels.

Therefore, the purpose of this work is to develop an algorithm which can accurately establish the mesh required for CFD simulation during the time marching process for a fourstroke direct-injection engine using gaseous fuel, i.e. compressed natural gas (CNG). This algorithm can also act as a coordinator for the CFD simulation as it remaps flow variables from the mesh in the previous time step to a new mesh is presented in Table 1.

There are three types of piston used, i.e. the flat piston, the homogeneous piston and the stratified piston. They have different crown geometry that influences the compression ratio of the engine. The use of plat piston results in a compression ratio of 10:1 whilst the other two types lead to a compression ratio of 14:1 which is more appropriate for CNG fuel. For the purpose of demonstrating the algorithm, only the flat piston is shown in this paper and the geometry of the one-cylinder model is depicted in Figure 1.

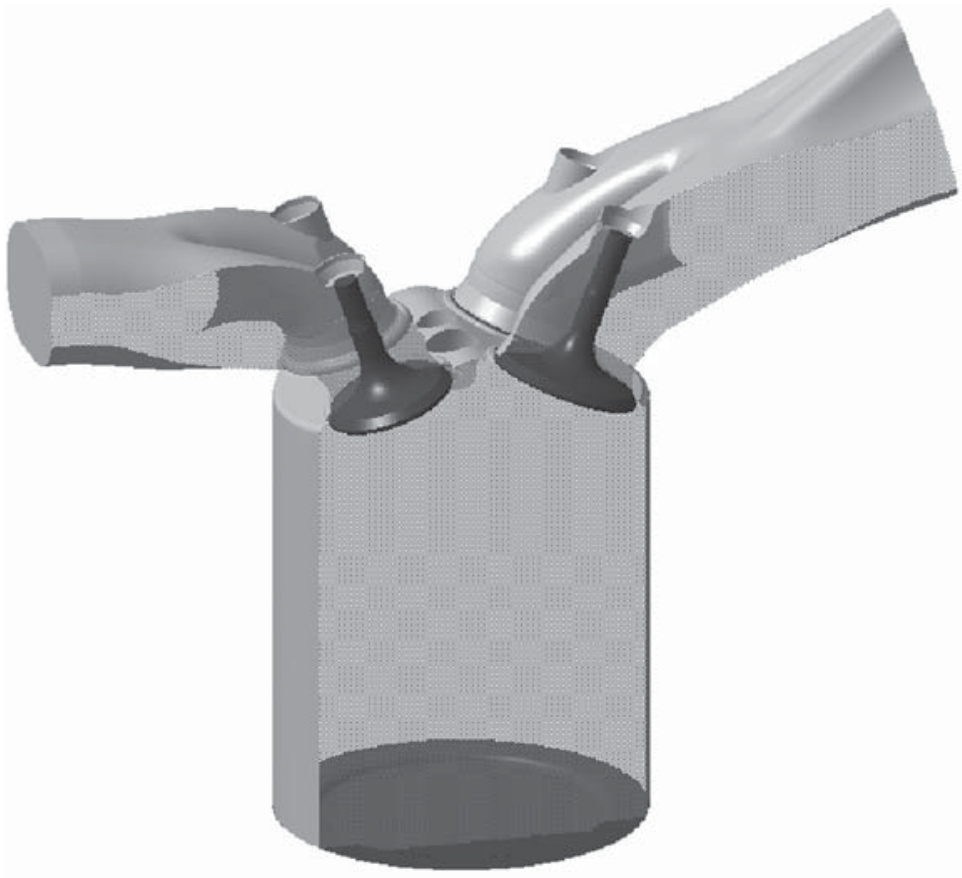

FIGURE 1. The geometry of the engine model

so that the contribution of transient terms in the flow formulation can be accurately modelled. This work is an extension to the work carried out by Kurniawan et al. (2005) who concentrate the development of half-engine model. However, for full combustion simulation, half model is not sufficient since it cannot simulate the presence of swirl and tumble flows and any unsymmetrical behaviour of in-cylinder fluid flow and combustion process.

\section{MODEL GENERATION AND SPECIFICATION}

In this paper, the development of moving mesh for a 1.6 litre four-cylinder four-stroke directinjection automotive engine was presented. The specification of the selected engine model

\section{METHODOLOGY OF MOVING MESH}

In general, the mesh can be subjected to translation and rotation, or can be distorted in any prescribed action by specifying time-varying positions for some or all of the cell vertices. This type of mesh movement, which is sometimes referred to as arbitrary Lagrangian-Eulerian, are able to accommodate a wide range of moving mesh and boundary problems, such as the type of CFD simulation under consideration.

The algorithm is written in the form of the STAR-CD ${ }^{\text {TM }}$ command or macro language since the simulation will later be executed by using the STAR-CD software, which is a commercial CFD code typically used in the automotive field. After establishing this moving mesh algorithm, analysis 
and investigation on air-fuel characteristics, fuel injection and ignition timing, flame propagation, combustion processes, exhaust emission and knock detection can be performed.

In this type of mesh problem as mentioned previously, an additional equation called the space conservation law is solved for the moving coordinate velocity components together with the mass and momentum equations so that the change in cell volume is related to the coordinate frame velocity. The simultaneous satisfaction of the space conservation law and all other equations of fluid motion facilitate the general operation of moving mesh. Mesh movement includes the arbitrary motion of the cell vertices which need to be handled carefully by working from the outset with the general forms of the governing differential equations in an arbitrary moving coordinate frame. The development and solution of the discretised forms of these equations are solved directly within the finite volume framework provided that appropriate measures are taken to ensure compliance to the space conservation law as a part of the PISO algorithm (Demirdžic and Peric 1988).

The set of equations describing the conservation of space, mass, momentum and energy in a moving coordinate frame can be mentioned respectively as (Warsi 1981;Demirdžic and Peric 1988)

$$
\begin{aligned}
& \frac{1}{\sqrt{g}} \frac{\partial \sqrt{g}}{\partial t}-\nabla \cdot v g=0 \\
& \frac{1}{\sqrt{g}} \frac{\partial}{\partial t}(\sqrt{g} \rho)-\nabla \cdot\left(\rho v_{r}\right)=0 \\
& \frac{1}{\sqrt{g}} \frac{\partial}{\partial t}(\sqrt{g} \rho v)+\nabla \cdot\left(\rho v_{r} v-T\right)=S_{v} \\
& \frac{1}{\sqrt{g}} \frac{\partial}{\partial t}(\sqrt{g} \rho \phi)+\nabla \cdot\left(\rho v_{r} \phi-q\right)=S_{\phi}
\end{aligned}
$$

where $\sqrt{ } \mathrm{g}$ is the determinant of the metric tensor, $v$ is the velocity vector, $v_{g}$ is the grid velocity, $v_{r}=v-v_{g}$ is the fluid velocity relative to the moving coordinate system (grid) and $\phi$ is a scalar quantity (temperature, concentration, etc). The terms on the right-hand sides of equations (3) and (4) represent sources or sinks. $T$ and $q$ are the stress tensor and the scalar flux vector, respectively given by

$$
\begin{aligned}
& T=-\left(p+\frac{2}{3} \mu \nabla \cdot v\right) I+2 \mu D \\
& q=\Gamma_{\phi} \nabla \phi
\end{aligned}
$$

where $p$ is the pressure, $\mu$ is the dynamic viscosity, $/$ is the unit tensor, $D$ is the deformation rate tensor (the symmetric part of the velocity gradient) and $\Gamma_{\phi}$ is the diffusivity of $\phi$.

Equation 1 could be used to calculate the change in cell volume, $\delta V$, for a given grid velocity $v_{g}$. This approach is relatively practical when the grid velocity is described below. Furthermore, in most practical applications, for example incylinder flow and flow around moving valves, the grid position at each time level is prescribed and the change in the cell volume as well as the surface vectors are given or known quantities.

In order to deal with the finite volume method for CFD calculation, Equation 1 is integrated over an arbitrary control volume (cell) and time, with the aid of the Gauss's divergence theorem to obtain the below equation as

$$
\frac{1}{\Delta t}\left(V^{n}-V^{o}\right)=\oint_{S} v_{g} \cdot d S^{n}
$$

where $\delta V=V^{n}-V^{\circ}$ is the change of the cell volume during $\Delta t, S$ is the surface of the control volume, $\mathrm{dS}$ is the surface vector and superscripts ' $n$ ' and ' $o$ ' denote the new and old time levels, respectively. For the Cartesian velocity components and arbitrary quadrilateral control volume as shown in Figure 2, equation (7) are derived to become as follows:

$$
\frac{1}{\Delta t}\left(V^{n}-V^{o}\right)=\sum_{i} v_{g i} S_{i}^{n}, i=\mathrm{e}, \mathrm{w}, \mathrm{n}, \mathrm{s},
$$

where $v_{g i}=\left(u_{g^{\prime}} v_{g}\right)_{i}$ is the cell face velocity and $S_{i}=\left(S_{x^{\prime}} S_{y}\right)_{i}$ is the cell face vector. In order to satisfy the space conservation law, the definition of the grid velocities should be made so that the rate of change of the cell volume obtained from the space conservation law, $\left(\delta V_{\mathrm{scL}}\right) / \Delta t$, is exactly equal to its actual or geometrical rate of change, $\left(\delta V_{G}\right) / \Delta t$, which is stated in the equation as

$$
\delta V_{G} \equiv \delta V_{S C L}
$$

This space conservation law concept and method will be applied to a complicated threedimensional case in a real internal combustion engine model. 


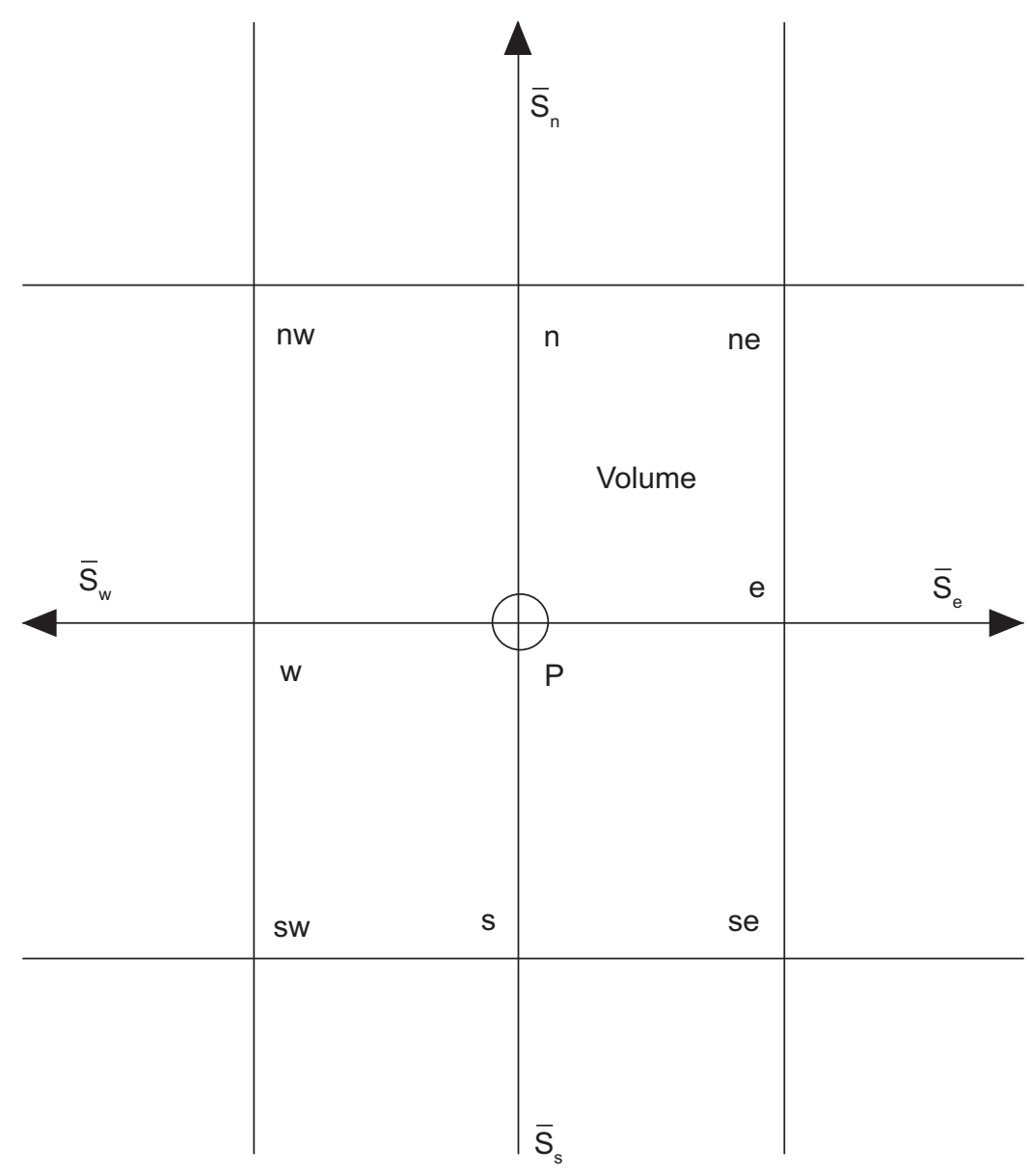

FIGURE 2. Control volume and labelling scheme

The typical fluid flow for the application of moving meshes in an internal combustion engine requires a large variation in the solution domain size. It can be mentioned that if the total number of cells in the solution domain remains fixed at certain time steps, the cell spacing inside the solution domain possible to become too dense at some stages of the solution and maybe too sparse at others. This circumstance is not favourable to be applied in the CFD simulation for the reasons as follows:

(a) The time step required to obtain a temporally accurate solution is dependent on the mesh Courant number. Hence, the unnecessarily small time steps will perhaps be necessary if the smaller cells are generated during the transient process, which will lead to longer computational times.

(b) The numerical instability problems associated with large aspect ratios might be occurred during unsteady calculation. Those potential problems can be overcome by enabling cells to be removed or added during the time marching process. Therefore, the average cell size can remain approximately the same.

The general principle in removal cells is that the mesh causes two or more opposing pairs of cell faces to become coincident at a specified time step, thereby causing all other faces to collapse to lines or points and thus making the cell disappear. On the other hand, the opposite process is used for cell addition. These processes could be performed on a more or less arbitrary selection of individual cells or a group of cells. However, in order to simplify addition and removal of cells, it can be applied to cell layers, i.e. assemblies of single-cell thickness. This is illustrated in Figure 3, which shows expansion and compression of a mesh within the cylinder and the intake port of an internal combustion engine.

In the development of the moving mesh for engine, the cell should have its preferable shape to move and squeeze within the layers of solution 


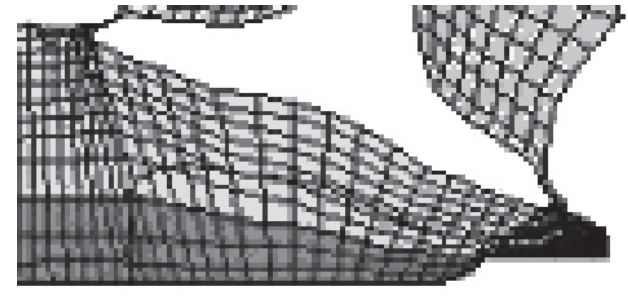

(a) Piston at top dead centre - most cell layers deactivated

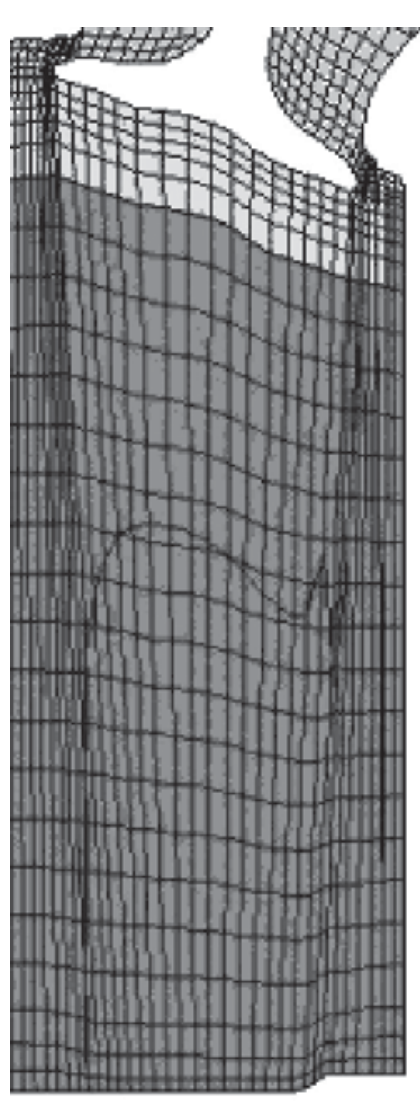

(c) Piston at bottom dead centre - most cell layers activated

FIGURE 3. Moving mesh for CFD simulation in the IC engine

domain. The cell shapes other than hexahedral cells may be difficult to identify layers belonged to those cells. There are some requirements which are to be considered in order to develop the moving mesh for an IC engine model, which are listed as follows (CD-Adapco Group 2004):

(a) The cells forming the outer periphery of the layer must lie adjacent to boundaries, which may be of any type of cells shapes.

(b) The faces which collapse must be quadrilaterals, but those that form the upper and lower surface of the layer may be of any standard shape (quadrilateral or triangular).

(c) Either the upper or lower surface of a layer may coincide in whole or part with a boundary, but not both surfaces simultaneously.

(d) Polyhedral cells can only be collapsed if they have been formed by extruding another cell in the direction of collapse.

(e) Layers may be added only if they were previously removed, and they should be re-inserted in reverse order of removal.
Although this may appear restrictive, it should be reiterated so that the removal process may be performed prior to the start of a fluids calculation.

(f) When the cell layers are restored, they will reacquire the boundaries they had when there were removed.

(g) Layers next to an arbitrary interface or region of embedded refinement may not be removed.

The cell removal process is accomplished presently with the aid of the general mesh motion procedure. This allows the faces of a cell to be moved in such a way as to shrink its volume to zero, on which it can be removed and then the mesh will arrange by itself. At the same time, the mass, momentum and energy associated with the cells in the layer to be removed are added to the cells in the neighbouring layer in a volumetrically conservative manner.

The cell addition process is operated in similar but reverse way. The difference is that it is necessary to initialize the variables of the 


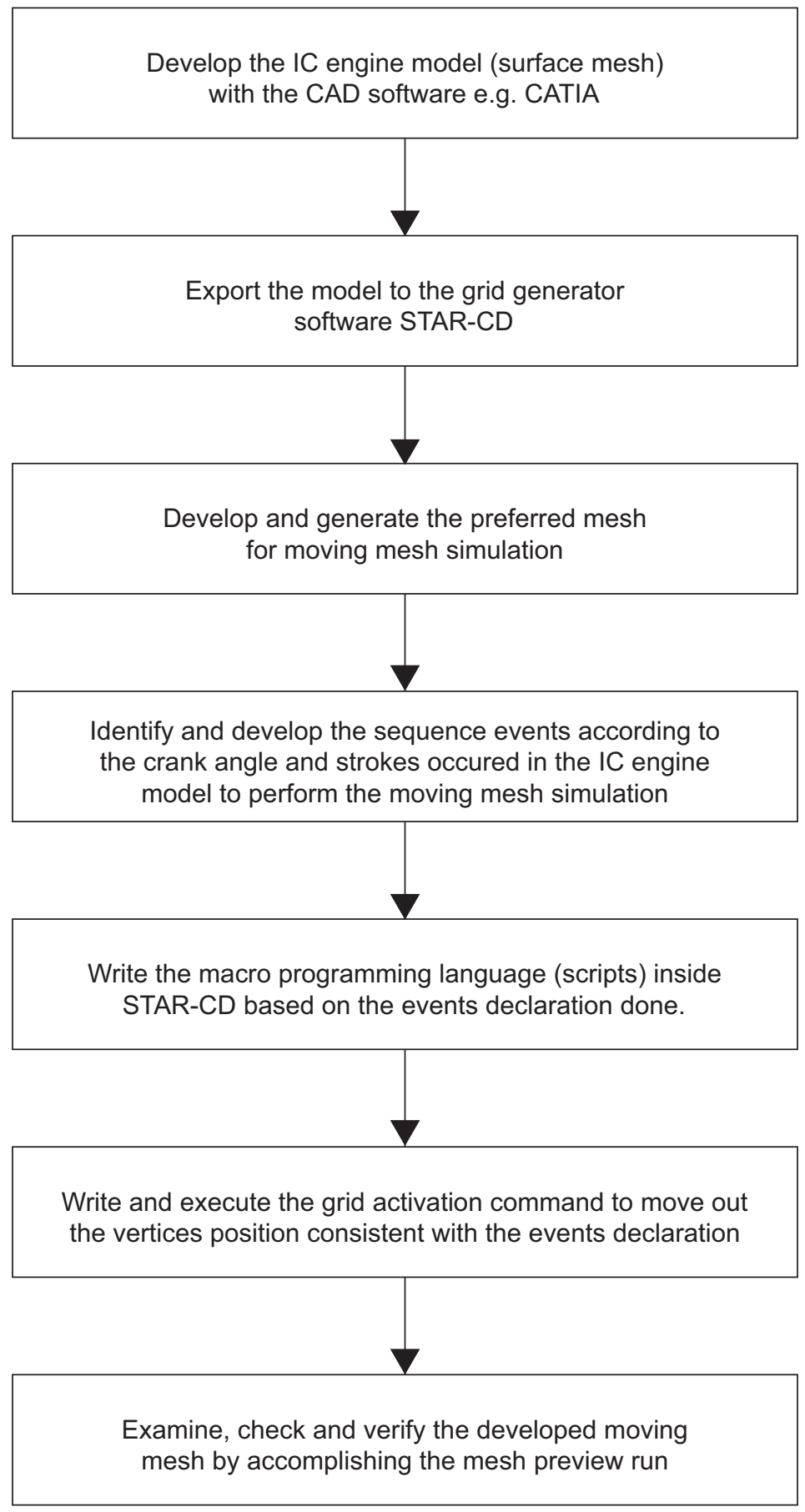

FIGURE 4. Flowchart for developing moving mesh algorithm

newly created grid node. This is carried out by appropriate mapping and interpolation techniques, i.e. the initial field values in the added layer are obtained by interpolation from neighbouring live cells. Here, conservation is assured by ensuring the zero volume of added cell layer.

Both the removal and addition procedures are performed without sacrificing the implicit method which is the preferred solution strategy for transient analysis. The general procedure for the whole process is illustrated in Figure 4.

\section{GRID AND EVENTS CODE GENERATION}

In order to build and develop the moving mesh for any particular application, the events should be provided and created in the form of programming language inside the STAR-CD 
software so that the mesh movement can be done by distorting and extruding the vertices of the cell layers of the engine model. In this case, events declaration is required to generate the time steps for every engine strokes. Then, the grid activation command is executed to move the vertices position within the mesh geometry based on the events declared. Changes in mesh geometry can be specified in the $X, Y$ and $Z$ axis either by STAR-CD output command or through customised coding in user subroutines. In the user subroutine, the geometry of the model can be varied by defining the coordinates of the vertex as a function of time or degree crank angle.

A simple moving mesh is illustrated in Figure 5 and the steps and STAR-CD command scripts required to perform this process are as stated below:

The below algorithm forms the basic concepts of developing moving mesh for the engine model which involves initialising and declaring

Step 1: Generate the mesh at certain time step (for example at time $t=0$ ):

TIME, TRANS (turn on the transient option)

MVGRID, ON, EVENT, PROSTAR (turn on the moving-grid option)

Step 2: Define an event step data file EVFILE, INITIAL, casename.evn EVSTEP, 1, TIME, 0.0

(initialise the events file)

EGRID, READ, casename.cgrd (define an event) (retrieve from file casename.cgrd regarding description of mesh operations in coded form)

EVSAVE, 1 (save as event no. 1)

Step 3: Create the casename.cgrd file as the grid activation command to move the vertices according to the event step data declared earlier.

VSET, NONE

VSET, ADD, VRANGE, 1, 2, 1

*SET, YPOST, TIME

VMOD, VSET, F, YPOST

VFILL, $1,11,4,3,2,2,1$ (clear the vertex set from the file)

(add vertices 1 and 2 to the set)

(set parameter YPOST equal to the current time)

(change the $y$-coordinate of the vertex set so that it refers to the lowest position of the mesh) (re-position the mesh vertices between the two boundaries)
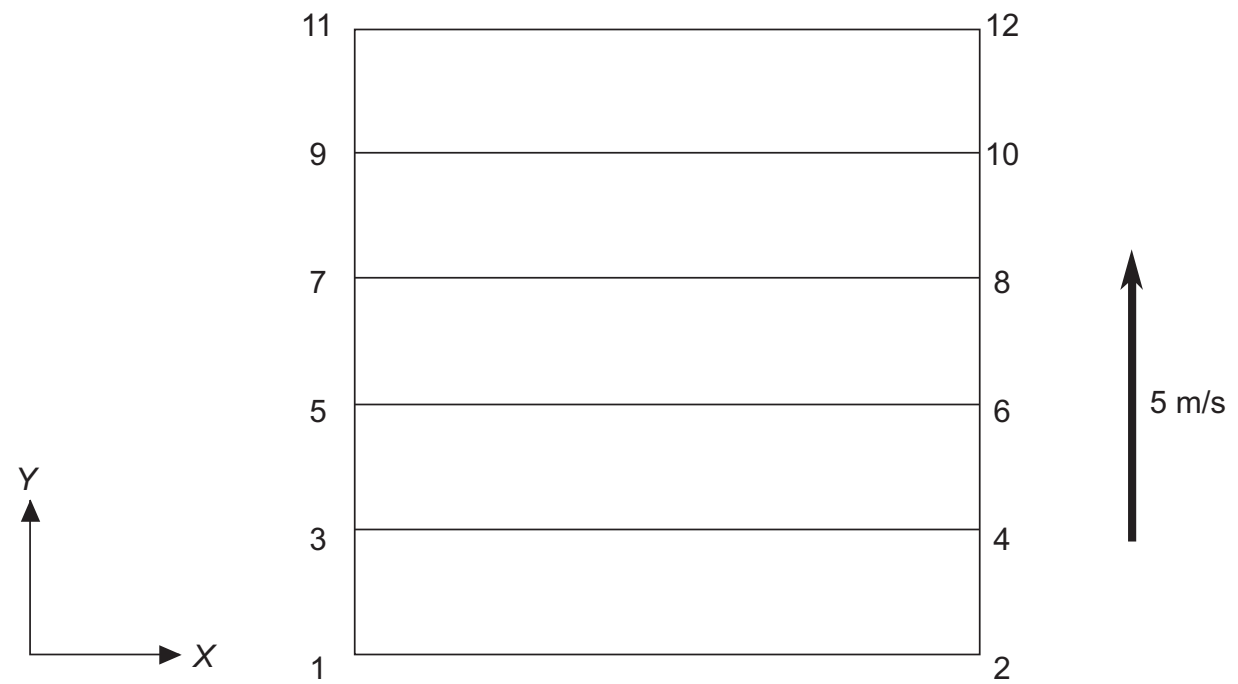

FIGURE 5. Simple moving mesh 
the events file before proceeding to creation of grid activation command to move and locate the mesh vertices in the model.

\section{MOVING MESH ALGORITHM FOR SINGLE CYLINDER MODEL}

In this section, the moving mesh for a single cylinder engine is developed in order to provide a preliminary study on the IC process which can later be validated through experiment on single cylinder engine test rig. Only after the combustion process is optimised, the overall performance of the whole engine can be analysed using the multi-cylinder moving mesh engine model.
The simulation results for the first three events $\left(348^{\circ} \mathrm{CA}, 360^{\circ} \mathrm{CA}\right.$ and $\left.468^{\circ} \mathrm{CA}\right)$ in the intake stroke are displayed in Figure 6.The intake valve starts to open while the exhaust valve is nearly close.This period is called valve overlap and it continues until the piston reaches TDC at the $360^{\circ} \mathrm{CA}$ as shown. Then, the intake valve travels until it reaches its maximum lift at the $468^{\circ} \mathrm{CA}$. During these periods, the active cell layers are in the intake valve, the exhaust valve and the cylinder so that their vertices at this engine parts need to be moved and positioned according to certain crank angle.

At the end of intake stroke, i.e. $540^{\circ} \mathrm{CA}$, the

TABLE 2. Degree of crank angle of single cylinder engine model for critical events

\begin{tabular}{cc}
\hline Crank Angle (degree) & Events \\
\hline 348 & Intake valve opening (valve overlap) \\
360 & Top dead centre (TDC) \\
468 & Maximum intake valve lift \\
540 & Bottom dead centre (BDC) \\
640 & Middle of compression stroke \\
720 & Top dead centre (TDC) \\
830 & Middle of power stroke \\
900 & Bottom dead centre (BDC) \\
973 & Maximum exhaust valve lift \\
1080 & Top dead centre (TDC) \\
\hline
\end{tabular}

The simulation of the moving mesh will be performed according to the crank angle which varies with every time step. The simulation of the engine cycle will include events for intake stroke, compression stroke, power stroke and exhaust stroke. Moreover, events for changes in positions for the intake and exhaust valves are also incorporated into the simulation. These important events are critical in order to produce a sound moving mesh for CFD calculation which is free from any negative volume. Table 2 lists some important degrees of crank angle that are plotted during the simulation. The simulation is subsequently performed for the full engine cycle on the moving mesh only, without fluid flow and combustion, in order to verify the algorithm for the moving mesh. piston is at the bottom dead centre (BDC) and the intake valve is near to its closed position as can be seen in Figure 7. At $640^{\circ} \mathrm{CA}$, the intake valve is already closed and piston moves up to do the compression stroke, where most of active cell layers during this compression stroke are the mesh layers in the cylinder. The cell layers at the vicinity of the intake valve are to be activated when the valve is nearly close until the piston reaches TDC. At $720^{\circ} \mathrm{CA}$, the piston is again at TDC and the intake and exhaust valves are closed to mark the end of compression stroke. There is no active cell layer at this position as most of the cell layers are deactivated.

Next, the simulation is performed during power stroke at $830^{\circ} \mathrm{CA}$ until $900^{\circ} \mathrm{CA}$ where the piston is at the $\mathrm{BDC}$ position which marks the 


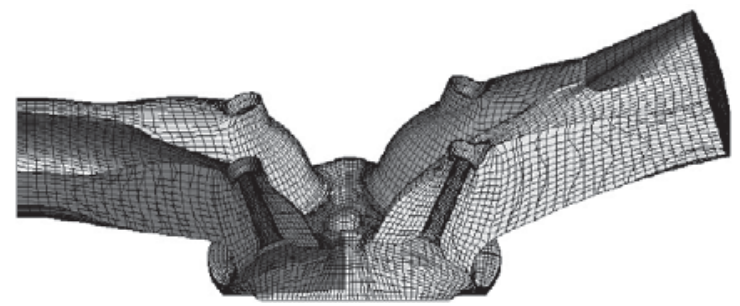

(a) Intake valve opening at $348^{\circ} \mathrm{CA}$

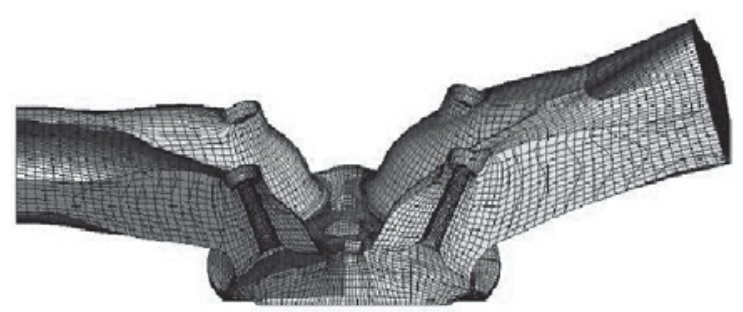

(b) Top dead centre at $360^{\circ} \mathrm{CA}$

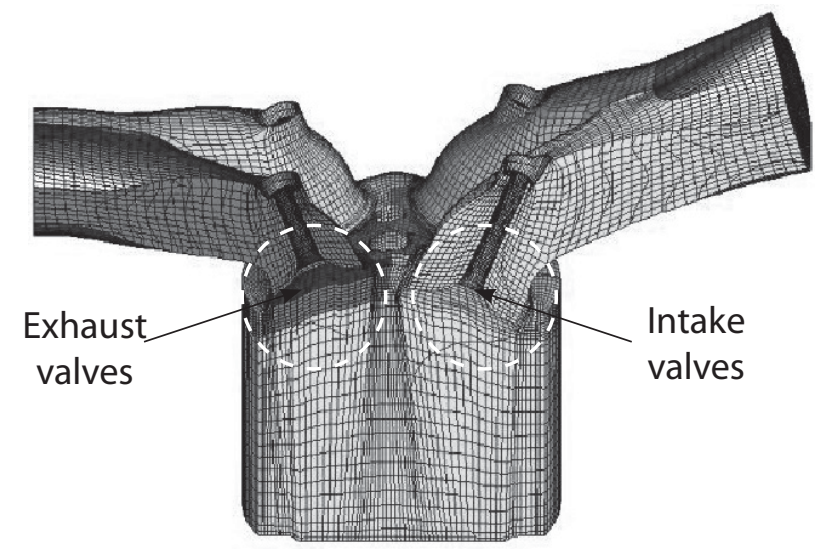

(c) Maximum intake valve lift at $468^{\circ} \mathrm{CA}$

FIGURE 6. Moving mesh during intake stroke

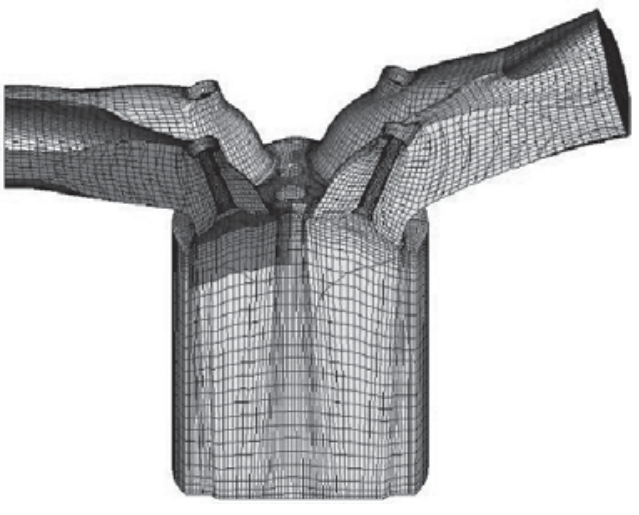

(a) End of intake stoke at $540^{\circ} \mathrm{CA}$

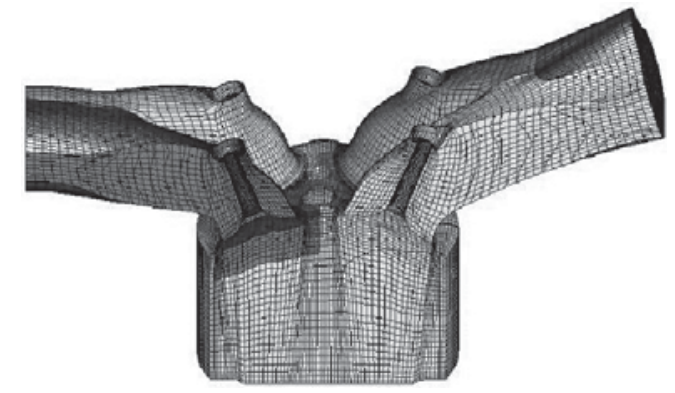

(b) Compression stroke at $640^{\circ} \mathrm{CA}$

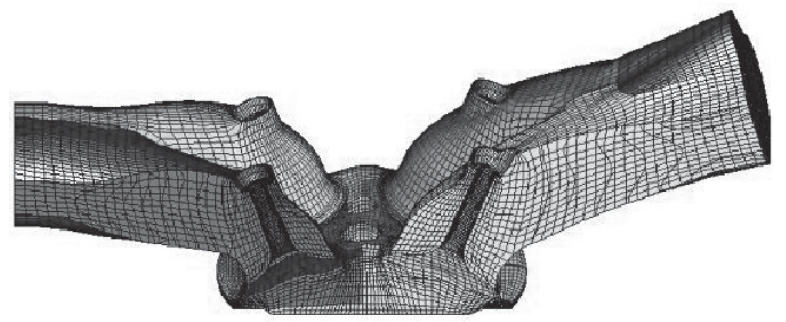

(c) End of compression stroke at $720^{\circ} \mathrm{CA}$

FIGURE 7. Moving mesh during compression stroke

end of the power stroke. At this moment, the exhaust valve is already open to mark the start of the exhaust stroke. Figure 8 illustrates the mesh position during the power stroke.

During the exhaust stroke, most of the cell layers in the cylinder are deactivated to move up with the piston until the exhaust valve reaches its maximum lift position. Then, when the exhaust valve is open to remove the exhaust gases, the cell layers at the exhaust valve and the cylinder will continue to be activated and deactivated respectively until the piston reaches the TDC position. The last part simulated in this work is the position of the piston at TDC $\left(1080^{\circ} \mathrm{CA}\right)$ after the end of exhaust stroke where both the intake and exhaust valves are closed and most of the cell layers are in non-active position. The simulation at the exhaust stroke is depicted in Figure 9. 


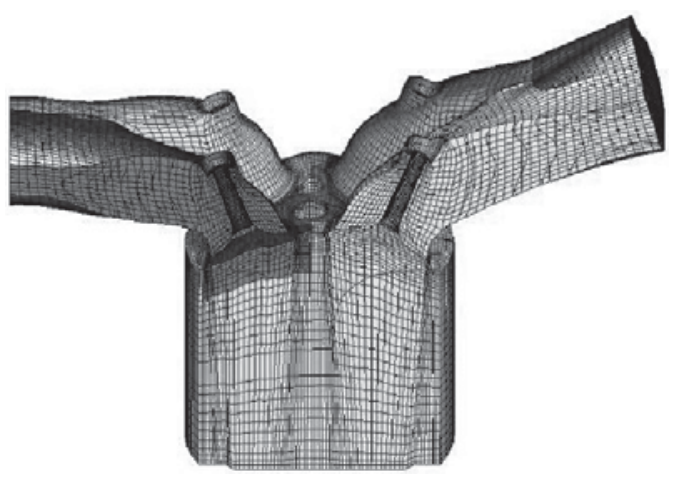

(a) Power stroke at $830^{\circ} \mathrm{CA}$

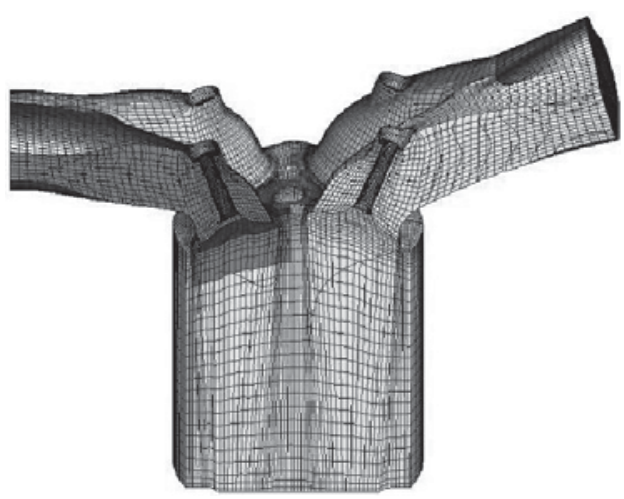

(b) Bottom dead centre at $900^{\circ} \mathrm{CA}$

FIGURE 8. Moving mesh during power stroke

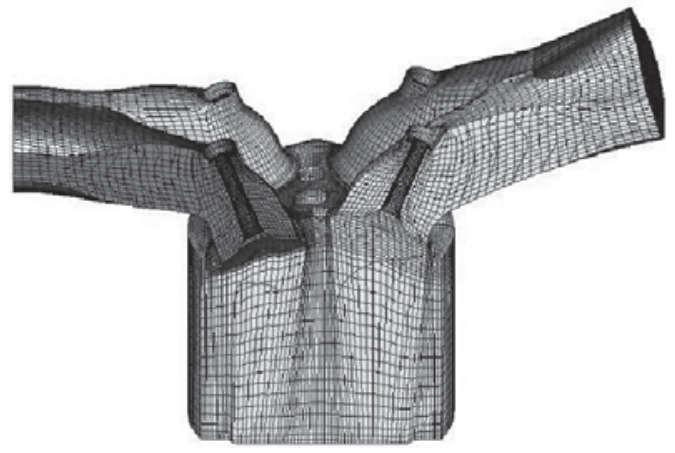

(a) Maximum exhaust valve lift at $973^{\circ} \mathrm{CA}$

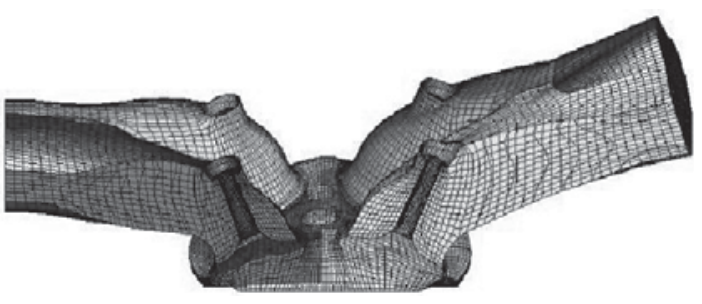

(b) Top dead centre at $1080^{\circ} \mathrm{CA}$

FIGURE 9. Moving mesh during exhaust stroke

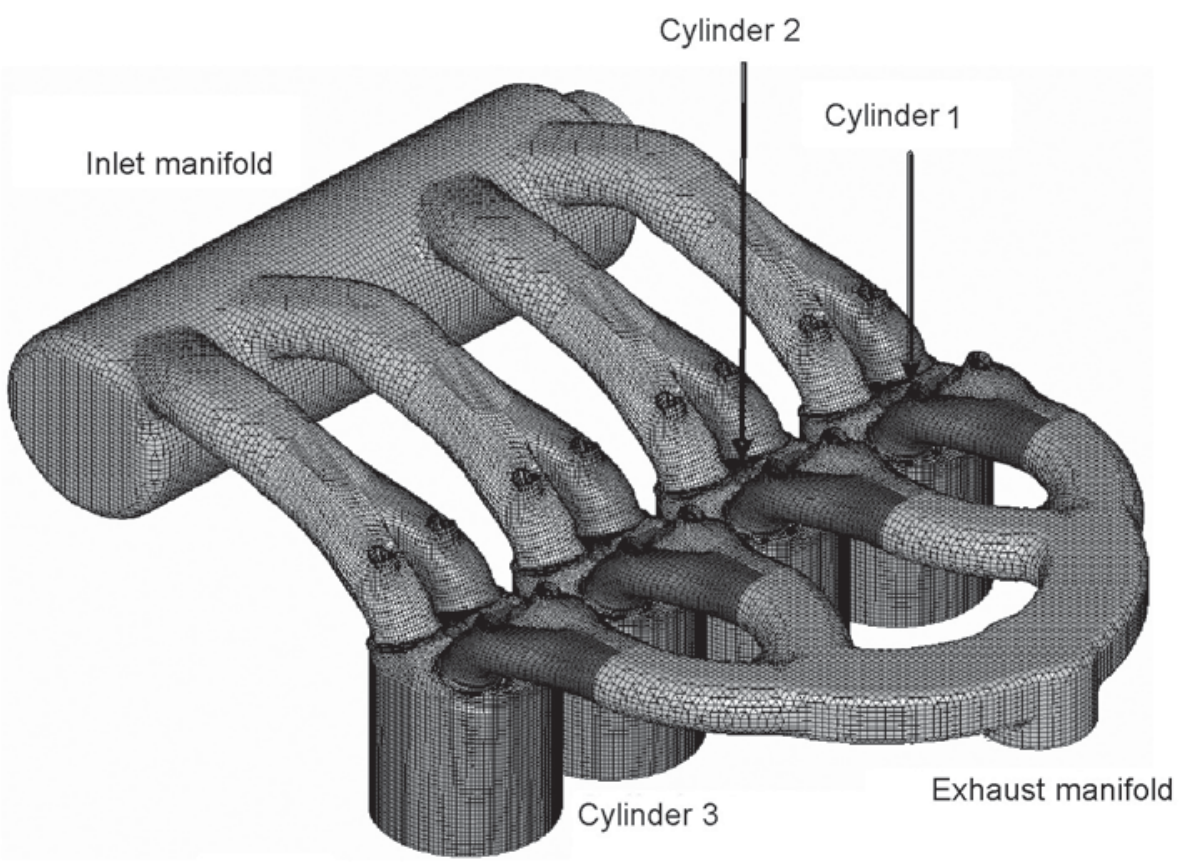

Cylinder 4

FIGURE 10.3D computational mesh of the multi-cylinder engine model 


\section{MOVING MESH ALGORITHM FOR MULTI CYLINDER MODEL}

After establishing the moving mesh concept for a single cylinder engine, this section will now present the moving mesh algorithm for multi-cylinder engine model by duplicating the cylinder into four units and adding inlet and exhaust manifolds in order to represent the whole engine unit. The full capacity of the engine is now $1596 \mathrm{~cm}^{3}$ (approximately 1.6 litre) representing four cylinders. As for this four cylinder engine, the combustion process is executed according to the firing order of 1-3-
4-2. Therefore, the execution of the developed algorithm follows the same order.

The simulation of the moving mesh for multi cylinder engine is also performed according to the crank angle, where each cylinder undergoes intake stroke, compression stroke, power stroke and exhaust stroke sequentially according to the firing order.The full three-dimensional model for the four-cylinder engine is shown in Figure 10.

The simulation results of the multi cylinder model for several important events are presented in Figures 11 and 12. These are for the maximum intake valve lift at $448^{\circ} \mathrm{CA}$ and the exhaust intake valve lift at $973^{\circ} \mathrm{CA}$, respectively. The sequence

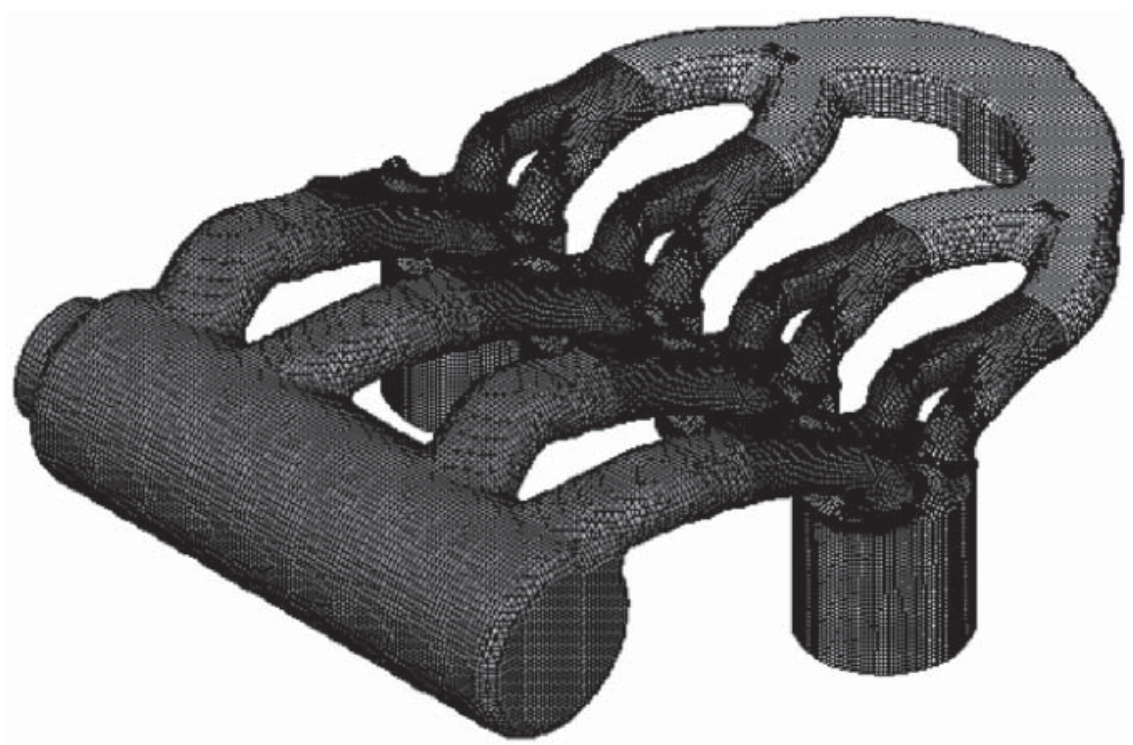

FIGURE 11. Multi cylinder model when cylinder 1 undergone maximum intake valve lift at $468^{\circ} \mathrm{CA}$

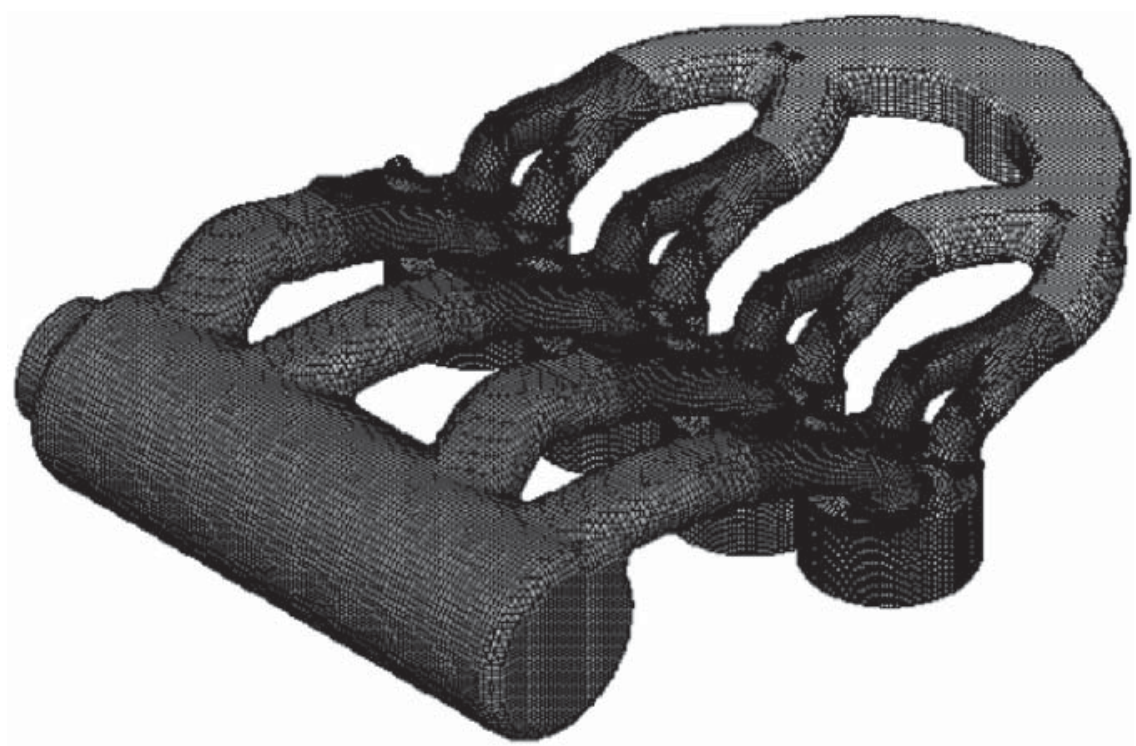

FIGURE 12. Multi cylinder model when cylinder 1 undergone maximum exhaust valve lift at $973^{\circ} \mathrm{CA}$ 
TABLE 4. The sequence event for each cylinder

\begin{tabular}{ccccc}
\hline \multirow{2}{*}{$\begin{array}{c}\text { Crank Angle } \\
\text { (degree) }\end{array}$} & \multicolumn{4}{c}{ Events (Defined Stroke) } \\
\cline { 2 - 5 } & Cylinder $\mathbf{1}$ & Cylinder 2 & Cylinder 3 & Cylinder 4 \\
\hline 360 & Intake & Exhaust & Compression & Power \\
540 & Compression & Intake & Power & Exhaust \\
720 & Power & Compression & Exhaust & Intake \\
900 & Exhaust & Power & Intake & Compression \\
1080 & TDC & BDC & BDC & TDC \\
\hline
\end{tabular}

of events of the full engine cycle for all cylinders is summarized in the Table 4.

\section{CONCLUSION AND FUTURE WORK}

In this paper, the development of moving mesh for the engine cycle simulation for a single and multi cylinder engine model is presented, where the algorithm required to perform in-cylinder fluid flow and combustion simulation is successfully developed. At all instances, the algorithm can capture and derive the required mesh as a function of crank angle. In each simulation, the position of the intake valve, exhaust valve and piston in the combustion chamber can be known and determined.

\section{REFERENCES}

Abd-Alla, G. H. 2002. Computer simulation of a fourstroke spark ignition engine. Energy Conversion and Management. 43:1043-1061.

CD-Adapco Group. 2004. STAR-CD Version 3.2 Methodology and User Guide. London: Computational Dynamics Limited.

Chen, A., Veshagh, A \& Wallace, S. 1998. Intake flow predictions of a transparent DI Diesel engine. SAE Paper 981020.

Choi, H., Kim, S.\& Min, K. 2001. Oxidation of unburned hydrocarbons from Crevices in spark-ignition engines. Proc $5^{\text {th }}$ International Symposium on Diagnostic and Modelling of Combustion in Internal Combustion Engines. Nagoya, Japan.

Demirdžic, I. 1982. A finite volume method for computation of fluid flow in complex geometries. PhD Thesis, University of London.

Demirdžic, I.\& Muzaferija, S. 1988. Numerical method for coupled fluid flow, heat transfer and stress analysis using unstructured moving meshes with cells of arbitrary topology. Computer Methods in Applied Mechanics and Engineering. 125:235-255.
For future work, the simulation is extended to investigate the combustion process, which included fuel injection and ignition, where appropriate boundary conditions will be applied to the computational mesh and the model executed to yield the simulated engine operating condition which can reduce dependency on experimental work of test rig when designing a new engine.

\section{ACKNOWLEDGEMENTS}

The authors would like to thank the Malaysian Ministry of Science, Technology and Innovation for sponsoring this work under the project IRPA 03-02-02-0057-PR0030/10-04.

Demirdžic, I. \& Peric, M. 1988. Space conservation law in finite volume calculation of fluid flow. International Journal of Numerical Methods in Fluids. 8: 1037-1050.

Hyun, G., Oguma, M. \& Goto, S. 2002. 3-D CFD analysis of the mixture formation process in an LPG DI SI engine for heavy duty vehicles. Proc. $12^{\text {th }}$ International Conference in Multidimensional Engine Modelling User Group Meeting - SAE Congress.

Wendy Hardyono Kurniawan, Azhari Shamsudeen \& Shahrir Abdullah. 2005. The development of moving mesh for the half-model simulation of a four-stroke automotive engine. Proc. National Seminar of Computational.

Payri, F., Benajes, J., Margot, X. \& Gil, A. 2004. CFD modelling of the in-cylinder flow in directinjection Diesel engines. Computers \& Fluids. 33: 995-1021.

Rifai, S. M., Buell, J. C., Johan, Z. \& Hughes, T. J. R. 2000. Automotive design applications of fluid flow simulation on parallel computing platforms. Computer Methods in Applied Mechanics and 
Engineering. 184: 449-466.

Thomas, P. D \& Lombard, C. K. 1979. Geometric conservation law and its application to flow computations on moving grids. AIAA Journal. 17:1030-1037.

Trulio,J.G.\&Trigger,K.R.1961.Numerical solution of the one-dimensional hydrodynamic equations in an arbitrary time-dependent coordinate system.
University of California Lawrence Radiation Laboratory Report UCLR-6522.

Warsi, Z. U. A. 1981. Conservation form of the Navier-Stokes equations in general nonsteady coordinates. AIAA Journal. 19: 240-242.

Yasar, O.2001. A new ignition model for spark-ignited engine simulations. Parallel Computing. 27: 179-200. 